\title{
Patterns of Use in an Online Catalog and a Card Catalog
}

\begin{abstract}
Will using an online catalog institute a change in patrons' catalog use patterns? In a study at the Ohio State University, success of patrons in finding titles in two department library card catalogs was compared with success in finding the same titles in the online catalog of three and one-half million records. During the study, information on patron use patterns was also obtained. In a later study, the success rate in searching titles of their own choosing in the online and card catalogs was measured. Results show that 90 percent of online users preferred the online to the card catalog; 64 percent of those who tried the online catalog switched to its use; patrons used the online catalog more often than the card catalog; and patrons' use of the card catalog decreased, but did not end.
\end{abstract}

\section{INTRODUCTION}

Academic libraries establishing an online catalog in the near future (particularly those in larger institutions) must determine how an online system will affect patterns of catalog use.

If dual systems are in effect, how will previous catalog use patterns change? Will the online catalog be used to the same degree as the card catalog or will card catalog use decrease as online use increases? If patrons switch back and forth between systems, will this interfere with their ability to use either system? Will the online system become a substitute for the card catalog or will patrons still depend upon the card catalog to search for certain items?

Extensive research has been done on cata$\log$ use $^{1}$ and concern is being focused on users of both card and online catalogs. Tagliacozzo and Kochen, authors of a major catalog use study, summarize these concerns:

Though many would agree that the manipulative acts required to use automated information re-

Sue Pease is reference librarian, Commerce Library, and librarian for labor education and research service, and Mary Noel Gouke is reference librarian, Education/Psychology Library, Ohio State University, Columbus. trieval systems may be different from those required to use traditional information systems, almost everybody seems to accept the assumption that the same basic cognitive processes are involved in both cases. Is this assumption justified? ${ }^{2}$

The authors did an experimental study of patron success and failure on known-item searches in the online and card catalogs at the Ohio State University libraries (in press, Journal of Academic Librarianship, July 1982). Data analyzed in this article are taken from a section on the questionnaire relating to comparative use of the online and card catalog by patrons. Data relate to their class, sex, and major, length of experience with the online system, and success and failure rates in both the online and card catalogs.

In addition to the experimental study described above, further research on actual searches brought to the library by patrons themselves has provided additional use data that will also be included.

The Ohio State University libraries provided an excellent setting for this research, since dual catalog systems have been in effect for the entire collection of three and one-half million volumes for ten years. These systems include a Union card catalog and an online catalog.

\section{Contents of the Online Catalog}

The online catalog contains: (1) a title and 
(2) an author record for every item represented in the Union card catalog. (Analytics are not included.) It also contains records for the following items not in the Union card catalog:

1. Items on order and in processing

2. Books owned by the State Library of Ohio

3. Special microform collections
a. ERIC documents
b. Human Relations Area File
c. Wing's Short Title Catalog (1641-1700)

\section{Points of Access to Records in the Online Catalog}

Authors-Author records for items cataloged by title main entry, or joint authors beyond the first author, were not included initially in the online catalog. (They have been included since 1977.)

Titles - A title entry is included for every record in the online catalog (including some items that do not have a title entry in the Union card catalog).

Added Entries - Added entries were not included initially in the online catalog. (They have been included since 1977.)

Cross-References-Cross-references were not included initially in the online catalog. (They have been included since 1977.)

Subject-Subject access using LC subject headings is available for all records cataloged since 1977.

Shelf List Position-A Union shelf list search may be done by call number revealing items adjacent to that call number in the Union shelf list.

\section{ForM OF RECORDS}

Each item in the online catalog has a oneline entry, giving author, title, and date of publication (or starting date for serials). The one-line entry gives access to a fuller circulation record, which gives the above information, plus the following: (1) call number, (2) library location(s), (3) availability for use and loan period, and (4) bound serial holdings, including indication of microform copies.

In addition to this shorter circulation record, a full bibliographic record may also be requested for all items cataloged since 1977.

The online catalog may be accessed by us- ing the following commands: title (TLS), author (AUT), author/title (ATS), subject (SIS), call number search (DSC), and shelf position search (SPS). Title searches, with which the authors' experimental study was primarily concerned, are done by using the TLS command, followed by a slash and an algorithm of four letters of the first word, followed by five letters of the second word. (Very common words that are not used are listed on a stop list posted on each terminal.) Patrons have had access to the online catalog for five years, and thirty-eight public terminals are available in the Main Library, with twenty-nine of these accessible on the first floor. There has been no queuing problem. One or more terminals are available in all department libraries.

A traditional card catalog system also is in operation with the Union card catalog in the Main Library and individual card catalogs in each department library.

Lack of Boolean logic in this system makes it atypical of new systems such as RLIN, WLN, etc., and findings in regard to patrons' ability with this system may not have relevance to systems in the future. The increased searching power of Boolean logic would, in cases of incorrect or incomplete information, lead to increased retrieval on the part of librarians and other skilled searchers. However, as far as the authors are aware, there are no studies showing that the average academic library patron would be able to take full advantage of this increased searching capability. In the authors' Departmental Libraries Experimental Study, there was a range of twenty-eight percentage points between the success of the patron sample and the success of a skilled librarian in using the online catalog. Patrons were not able to utilize fully the searching power of the online catalog as compared with the skilled searcher. This indicates that the average user of the online catalog may have greater difficulty with a more complex system offering more options and utilizing Boolean logic.

\section{METHOD}

The Department Libraries Experimental Study was conducted in two of the largest departmental libraries in the Ohio State University Library System: the Commerce Library and Education Library. Success of 
patrons in finding titles in the two department library card catalogs was compared with success in finding the same titles in the online catalog of three and one-half million records.

Using random selection, fifty-two titles were drawn from each library card catalog and each title was verified in the online cata$\log$ to assure its existence in the system. The 104 patrons (52 in each library) in the study were chosen at predetermined random times from those using the public terminals in each library. This was done in order to assure that the patron had some familiarity with the online catalog.

Patrons were selected by random methods, and length of experience with the online catalog varied from several days to five years. The sample contained both experienced and inexperienced users. Each patron was asked if he or she would participate in a brief experiment on improving use of the online catalog. After agreeing to participate, the patron then checked off information on a brief questionnaire.

If the patron was to begin at the card cata$\log$, she/he was taken from the terminal to the card catalog. If to begin at the terminal, she/he remained there and was given a folded title sheet and requested to locate the title in the online system. A five-minute time limit was set for the search and for writing the call number on the sheet. For the next step, the title sheet was turned over and a search was made for the same title in the card catalog using the same time limit. The reverse of this procedure was made with the next patron and this rotation continued for the duration of the project.

The time taken searching each title, the patron's search patterns and algorithms used from the terminal screen, and his or her search patterns in the card catalog were recorded.

\section{Main Library “Actual” Searches Study}

After the completion of the experimental study in the department libraries described above, a study of actual card catalog use was done in the Main Library. Two forms on which patrons could record their own searches at the online and card catalogs were prepared and pretested. Extensive pretesting of the forms was done until the authors were satisfied that accurate records of known-item and subject searches were being obtained. Forms were passed out to patrons in the Main Library over a four-week period. Participants were chosen from those using the four IBM 3278-2 terminals located in the lobby with the Union card catalog. Patrons deposited forms in a marked box before leaving the area. A determined effort was made to retrieve each form handed out. The return rate of forms was around 95 percent.

\section{Use Data From Aвove Two Studies}

In the Department Libraries Experimental Study, the brief questionnaire filled out by each patron before beginning to search requested:

1. the patron's class or status

2. major area of study

3. how long he/she had used the online catalog

4. frequency of use of:

a. the online catalog per month

b. the card catalog per month

In the Main Library Actual Searches Study, patrons using the online and card catalogs gave information on class, major area, their use of both catalogs, and the reason for this use.

\section{Results}

Table 1 shows the classes of patrons in the authors' two studies, the Department Libraries Experimental Study and the Main Library Actual Searches Study. A comparison is made with the Specht study done at the University of Illinois using the same online system. ${ }^{3}$ Table 2 shows the length of patrons' online experience in the Department Libraries Experimental Study and the Main Library Actual Searches Study.

The study indicates that the proportion of graduate and undergraduate users at the online catalog varies in different libraries. Comparison was made in the Main Library where samples were taken at both the online and card catalog. At the Main Library, patrons using the card catalog were of a lower class level (freshmen, sophomore) than those using the online catalog.

\section{Preference for the Online Catalog}

Four studies of online users have now been published. ${ }^{4}$ Three of these studies asked pa- 
TABLE 1

Class of Patrons in Three Online Catalog Studies

\begin{tabular}{|c|c|c|c|c|c|c|c|c|c|c|}
\hline & \multicolumn{3}{|c|}{$\begin{array}{l}\text { Department Libraries } \\
\text { Experimental Study }\end{array}$} & \multicolumn{6}{|c|}{$\begin{array}{l}\text { Main Library } \\
\text { Actual Study }\end{array}$} & \multirow{4}{*}{$\begin{array}{c}\text { Found at } \\
\text { Online Catalog } \\
\text { Specht Study } \\
\text { Illinois } \\
\text { Main Library } \\
(\%)\end{array}$} \\
\hline & \multirow{2}{*}{\multicolumn{2}{|c|}{$\begin{array}{l}\text { Found At } \\
\text { Online Catalog } \\
\text { Terminals }\end{array}$}} & \multirow{3}{*}{$\begin{array}{l}\text { Undergrds } \\
\text { And } \\
\text { Grads } \\
\text { (\%) }\end{array}$} & \multirow{2}{*}{\multicolumn{2}{|c|}{$\begin{array}{l}\text { Found At } \\
\text { Online Catalog } \\
\text { Terminals }\end{array}$}} & \multirow{3}{*}{$\begin{array}{l}\text { Undergrds } \\
\text { And } \\
\text { Grads } \\
\text { (\%) }\end{array}$} & \multirow{2}{*}{\multicolumn{2}{|c|}{$\begin{array}{c}\text { Found At } \\
\text { Card } \\
\text { Catalog }\end{array}$}} & \multirow{3}{*}{$\begin{array}{l}\text { Undergrds } \\
\text { And } \\
\text { Grads } \\
(\%)\end{array}$} & \\
\hline & & & & & & & & & & \\
\hline & Number & Percent & & Number & Percent & & Number & Percent & & \\
\hline Freshman & 5 & $5)$ & & 4 & $11)$ & & 5 & $8)$ & & \\
\hline Sophomores & 4 & 4 & & 6 & 16 & & 15 & 24 & & \\
\hline Juniors & 16 & 16 & 49 & 7 & 18 & 66 & 7 & 11 & 75 & 54 \\
\hline Seniors & 24 & $24\}$ & & 8 & 21) & & 20 & $32)$ & & ) \\
\hline Grads & 51 & 51 & 51 & 13 & 34 & 34 & 16 & 25 & 25 & 46 \\
\hline Totals & 100 & 100 & & 38 & 100 & & 63 & 100 & & \\
\hline
\end{tabular}

TABLE 2

LENGTH of PAtrons' EXPERIENCE WITH THE ONLINE Catalog

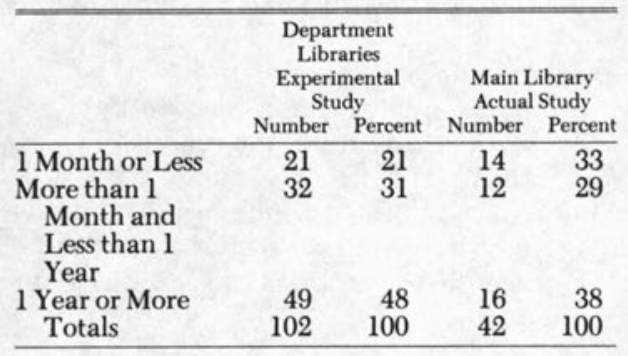

trons for their preference, and results indicated a preference for the online catalog by users (see table 3).

These studies indicate that users will accept a catalog in the online format. For more data on reasons for this preference, see Moore. ${ }^{5}$ The question as to what extent users will accept the online catalog as a substitute for the card catalog is not answered. Perhaps user behavior in a system such as that of the Ohio State University libraries, where dual systems have been available for some time, will indicate the extent to which this online catalog has become a substitute for the card catalog.

\section{Patrons Found at the Online Catalog}

This online catalog has certain advantages over the card catalog, including greater currency (four to six weeks for main entries), availability of circulation information, complete bound serials holdings, additional individual records for each item in certain microform series that are not analyzed indi- vidually in the card catalog, and greater ease of use. Based on these advantages and on patrons' preference, indications are that almost all patrons who try the online catalog will change over to using it more often than the card catalog. If we study patrons found at the online catalog and consider their use patterns in relation to their expressed preference, this appears to be so (see table 4).

The use patterns reported by those found at the online catalog in the authors' earlier Department Libraries Study parallel the use patterns of those found at the online catalog in the Main Library Actual Searches Study. In evaluating these results, does a sample of online users give a fair representation of all patrons who have tried the online catalog, did not like it, and returned to card catalog use? This theory is examined in the section on

TABLE 3

Preference for Online Catalog

\begin{tabular}{lll}
\hline \hline \multicolumn{1}{c}{ Dowlin } & \multicolumn{1}{c}{ Moore } & $\begin{array}{c}\text { Gouke And Pease } \\
\text { Experimental } \\
\text { Study }\end{array}$ \\
\hline $\begin{array}{l}85.4 \% \\
(\text { w/ subject } \\
\text { access }-94 \%)\end{array}$ & $\begin{array}{l}\text { 2. Preferred Choice } \\
\text { in all four } \\
\text { systems surveyed }\end{array}$ & 3. $90 \%$ \\
\hline
\end{tabular}

TABLE 4

Preference and Use Patterns of Users Found at the Online Catalog

\begin{tabular}{lcc}
\hline \hline & $\begin{array}{c}\text { Prefer } \\
\text { Online } \\
(\%)\end{array}$ & $\begin{array}{c}\text { Use Online } \\
\text { Catalog } \\
\text { More Often } \\
(\%)\end{array}$ \\
\hline Department Libraries & 90 & 86 \\
Main Library & - & 91 \\
\hline
\end{tabular}


"Patrons Found at the Card Catalog" in this article.

The reasons why patrons preferred the online catalog to the card catalog were not studied in depth by the authors because the focus of the study was on collecting data on patron success and use patterns, and because this information is being researched and is available in other papers, particularly that of Carol Weiss Moore. ${ }^{5}$

\section{Use Patterns of Online Catalog Users:}

DEPARTMENT LIBRARIES EXPERIMENTAL STUDY

1. Online catalog patrons reported that their use of the card catalog decreased but did not stop altogether.

Comparing both libraries, card catalog use averaged 3.4 uses per month at the time patrons began to use the online catalog. The sample of patrons who had used the online catalog more than one year had a card cata$\log$ rate of only 1.9 uses per month (see figure 1).

The degree of the drop in card catalog use may depend upon whether patrons were heavy or light users of the card catalog. If card catalog use was high, as in the Commerce Library (5.6 uses per month), it dropped sharply and then leveled out. If it was low (1.2 uses per month), as in the Education Library, it continued low, with a very slight rise (see figure 2).

2. A majority of patrons found at the online catalog changed over and began to use the on-line catalog more frequently per

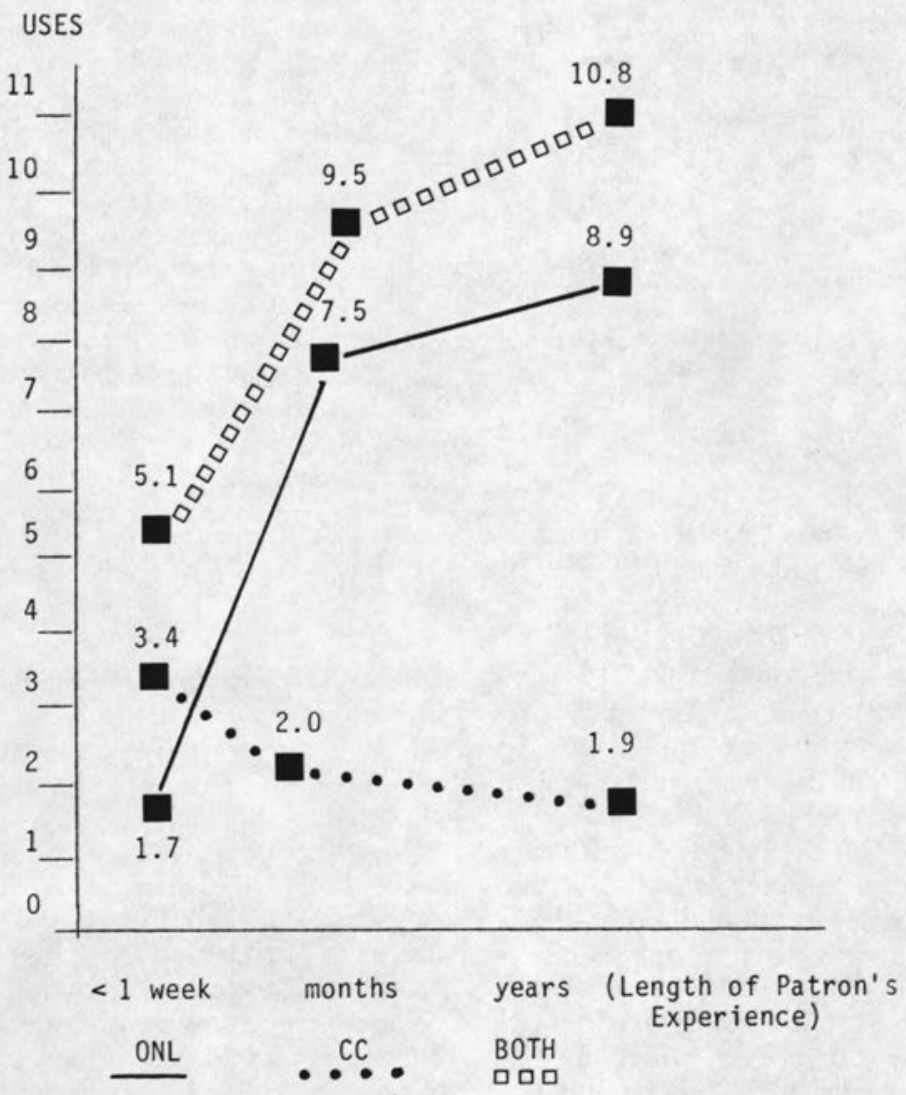

Fig. 1

Department Libraries Experimental Study Uses Per Month of the Online Catalog and Card Catalog Related to Length of Patron's Experience with the Online Catalog: Mean for Both Libraries 


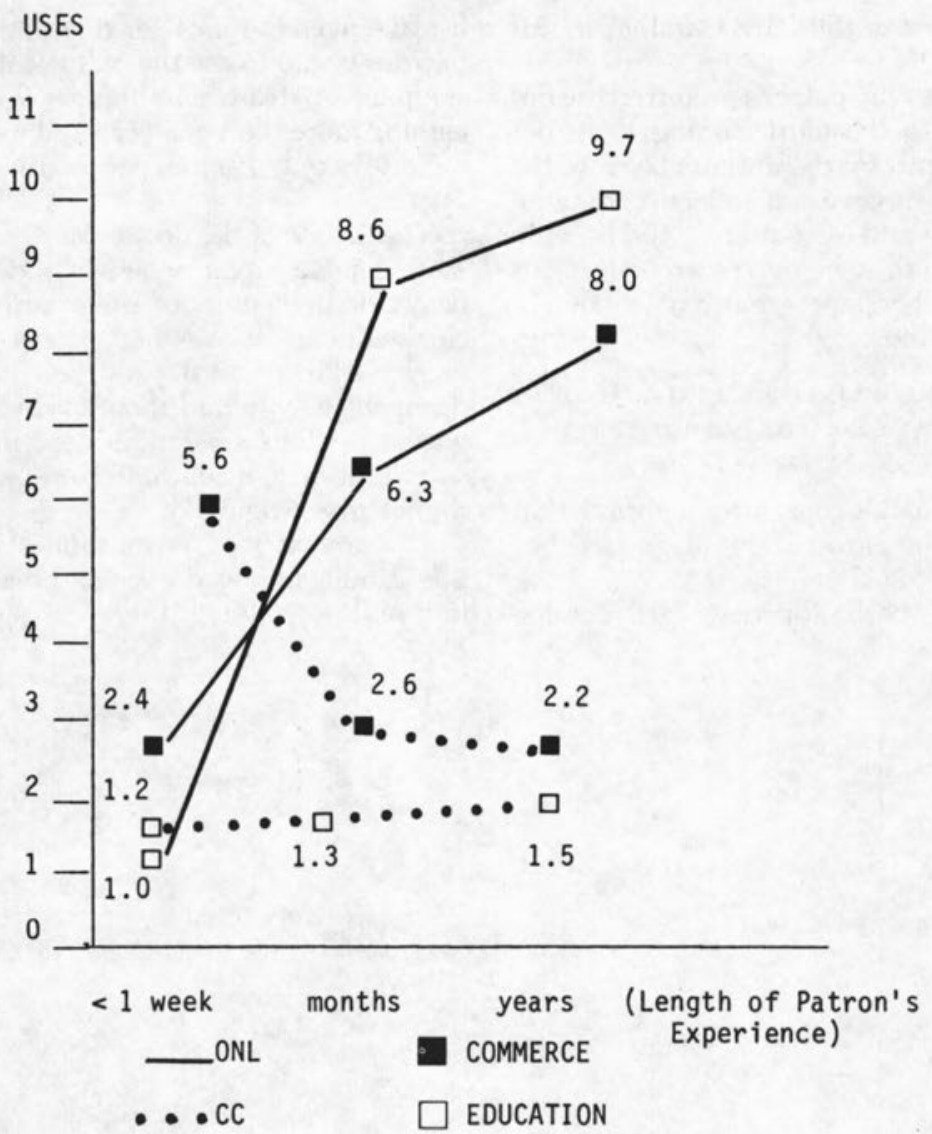

Fig. 2

Department Library Experimental Study Uses Per Month of the Online Catalog and Card Catalog Related to Length of Patron's Experience with the Online Catalog: Commerce Library and Education Library

month than the card catalog.

Figure 1 indicates that sometime during or after the first month of use, online catalog use rose dramatically from 1.7 uses per month to 7.5 uses per month, or a 341 percent rise. After the sharp rise in the first year, frequency of online use continued to rise, but more gradually to a mean high point of 8.9 online uses per month after patrons had used the online catalog for more than a year.

This early changeover is supported by answers to the check question, "Which catalog do you use more often?" After less than a month of use of the online catalog, 55 percent reported using it more often than the card catalog. After some months of use, 84 per- cent reported using it more often than the card catalog.

3. Patrons reported using the online catalog more often than the card catalog. This is supported by the statistics.

Using one class level as an example: graduates beginning to use the online catalog made 4.9 searches per month in the card catalog. Graduates having used the online catalog for more than a year made 10.8 online uses and 2.7 card catalog uses per month for a total of 13.5 uses per month. (See tables 1 and 2 for a sample description in the Department Libraries Experimental Study.)

Indications are that patrons are accessing the library's holdings records more fre- 
quently than they did in the past when patron use was limited only to the card catalog. If no card catalog existed, these patrons would probably be accessing the library's online holdings more frequently than they currently use the card catalog (see figure 1). This is supported by results from the OSU Poll, winter quarter, 1981 (Library Section), where 363 students at all levels reported more uses per month of the online catalog than of the card catalog. ${ }^{6}$ (See table 5.)

Patterns of use for patrons found at the online catalog in the Main Library Actual Searches Study is shown in table 6.

\section{Patrons Found at the Card Catalog: Residual Card Catalog Use}

Does a group of "drop-out" users who tried the online catalog and then returned to card catalog use exist? If so, perhaps these patrons will not use the online catalog frequently enough to be represented in the sample of online users.

\section{TABLE 5}

OSU Poll Results for Student Sample MEAN NUMBER OF USERS PER MONTH PER Person in Online and Card Catalogs by Class

\begin{tabular}{lccc}
\hline & $\begin{array}{c}\text { Online } \\
\text { Catalog }\end{array}$ & $\begin{array}{c}\text { Card } \\
\text { Catalog }\end{array}$ & \multicolumn{1}{c}{ Difference } \\
\hline Grads & 8.8 & 6.7 & 2.1 \\
Seniors & 4.3 & 3.9 & $.4)$ \\
Juniors & 3.9 & 3.3 & $.6)$ \\
Sophomores & 4.0 & 2.9 & 1.1 \\
Freshmen & 3.6 & 2.3 & $1.3)$ \\
$\quad$ Total & 24.6 & 19.1 & \\
& 4.9 & 3.8 & \\
\hline
\end{tabular}

No study, as yet found, has been made that includes both users found at the terminals and the card catalog. In studies by Specht, ${ }^{7}$ Moore ${ }^{8}$ and in the Department Libraries Experimental Study, the only patrons surveyed were those found already using the online catalog. In the Dowlin study, patrons entering were surveyed and, if they had not previously been introduced to the online catalog, were given a lesson in its use. ${ }^{9}$ Their preference was based on a very brief acquaintance and was not extensive enough to predict their actual use pattern in the future.

The question as to whether a group of "drop-out" online users exists and may be found at the card catalog was investigated in the authors' study of actual searches in the Main Library. Both online and card catalog users were surveyed, and use patterns were studied for both groups.

A description of patrons found at the card catalog is given in table 7. Table 7 and figure 3 show that the majority of users at the card catalog had been acquainted with the online catalog.

Considering the advantages of the online catalog, why were so many online users found at the card catalog? The majority ( 30 percent) were there because of a general lack of confidence in the online catalog derived from disappointing past experience. However, they did continue to use the online catalog when they did not find the desired item in the card catalog. Typical comments of this group were:

"More familiar with card catalog."

"I have greater confidence in the card catalog."

"I always start with the card catalog."

"I couldn't get it to work."

\section{TABLE 6}

Main Library Actual Searches Study

Patrons Found at the Online Catalog

Predominant PATterns of USE

Use online only

(No cross-checking card catalog)

Use online more often

(Will cross-check card catalog if don't find)

Use card catalog more often. In this

particular case was at online because

ailed at card catalog

Use selectively about the same amount 
TABLE 7

\author{
Main Library Actual Searches Study \\ Patrons Found at Card Catalog \\ Predominant Patterns of Use
}

\begin{tabular}{lcc}
\hline \hline & Number & Percent \\
\hline $\begin{array}{l}\text { Have never used online. Don't know how } \\
\text { Have used online, but still prefer and use card catalog more often. Will } \\
\text { cross-check in online if not found }\end{array}$ & 24 & 30 (drop-out users) \\
$\begin{array}{l}\text { Use online most of time, but came to card catalog because failed to find } \\
\text { what was wanted in online }\end{array}$ & 13 & 16 \\
$\begin{array}{l}\text { Use both selectively about same amount. Thought this particular search } \\
\text { would be more successful and/or faster at card catalog }\end{array}$ & 6 & 7.5 \\
$\begin{array}{l}\text { At card catalog because used online in past and got poor results. Didn't } \\
\text { like and stopped using }\end{array}$ & 2 & 2.5 (drop-out users) \\
$\quad$ Totals & 80 & 100 \\
\hline
\end{tabular}

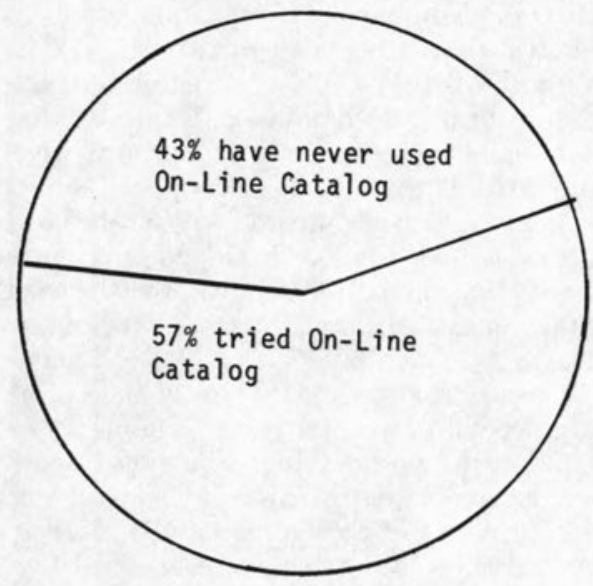

Fig. 3

Main Library Actual Searches Study Percent of Card Catalog Users Surveyed Who Have Tried Online Catalog

"Instructions were unclear."

Another group (2.5 percent) was there due to an attitude of strong dislike for the online catalog on the basis of unsatisfactory past experiences.

"The card catalog for me is very, very useful and when I have asked anyone (library staff) to search in the machine for an item, they have never come up with any information useful to me except to tell me if the book was out. Even periodicals seem difficult to find computer-style."

"The instruction I have received for LCS, both written and oral, has been lousy. LCS has not worked well for me."

"Hate computers."

Other users were there for specific reasons related to the particular search they were doing. Sixteen percent were there crosschecking because they had failed to find what they wanted in the online catalog. Another 7.5 percent were there because they were selective users of both catalogs. They came first to the card catalog because they believed it would yield the most satisfactory results on their particular type of search. Typical comments were:

"I'm looking for 1937 material which is not on the computer under subject search."

"I felt title given by professor was probably incorrect."

"If I look for something specific I go to the computer, otherwise, to card catalog."

"Didn't think one could search by subject on the computer."

"Wasn't sure if it was a valid subject heading, but I see it is."

Several of these comments indicate that when there was doubt about the accuracy of the information in hand, the card catalog was preferred. Further research should be done in this area.

\section{Drop-Out OnLine USERS}

As can be seen in table 7, when the users of the card catalog in the Main Library were surveyed, the above-mentioned theory was supported and a group of drop-out online users was found that continued to prefer the card catalog and to use it more often. When this group was added to the online users found at the terminals, the online catalog remained the most frequently used, but the switchover to the online catalog was less pronounced than appeared from a survey of online users only. Figure 4 shows the figures for online users found at the terminals and the 


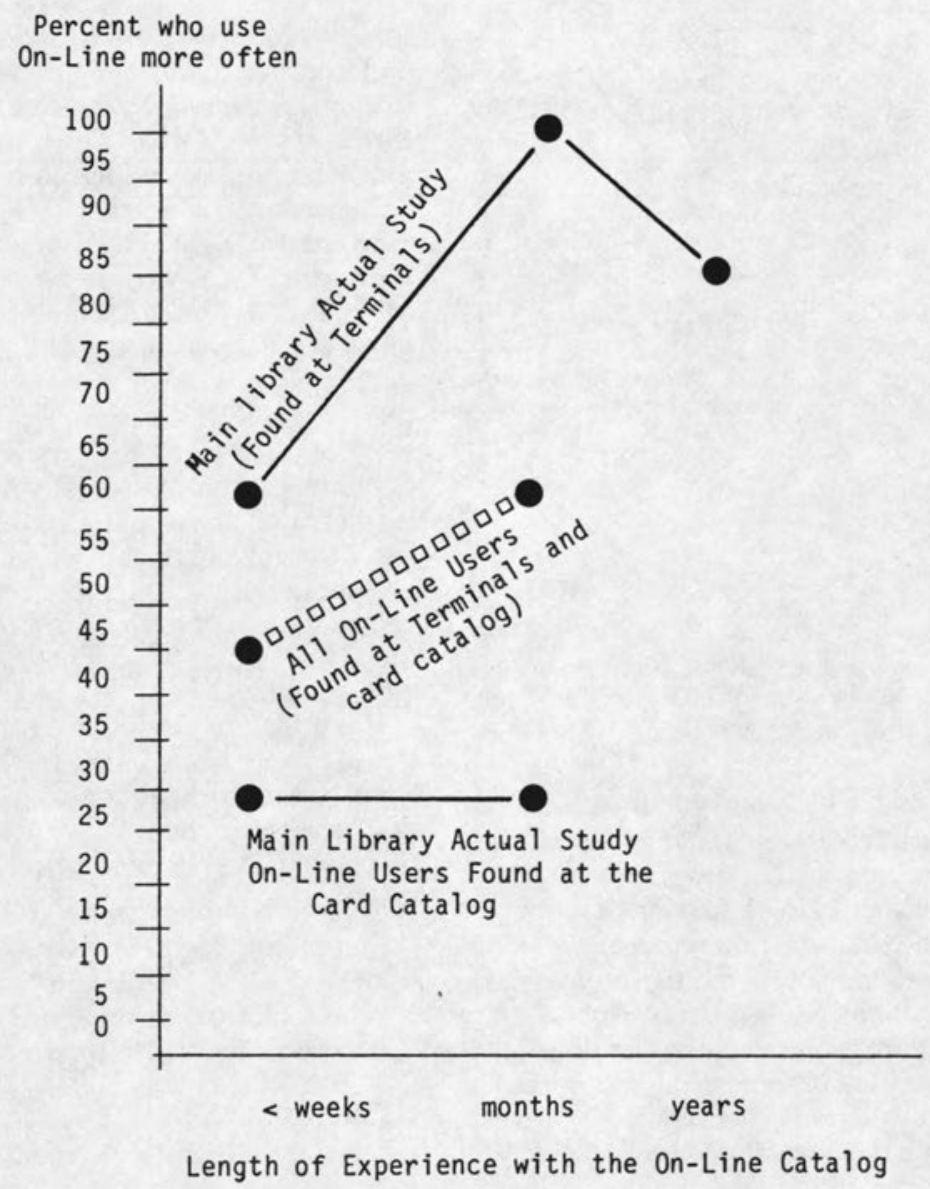

Fig. 4

Main Library Actual Searches Study Percent of Online Users Who Use Online More Often

entire group of online users, including those found at the card catalog. The center dotted line represents all online users, regardless of where found. The graph in figure 5 represents all patrons who have tried the online catalog.

The basic reason that this group of dropout users continued to use the card catalog more frequently was not dislike of the online catalog ( 25 percent of total drop-out users table 7), but lack of confidence in the online catalog and in their ability to use it. They felt the card catalog was faster, easier, and that they were more successful with it.

This group of users resembled those who had never used the online catalog in class level, but they differed in one respect. While they preferred to use the card catalog, and expressed reservations about the online cata$\log$, a large proportion reported they intended to use it for a cross-check when the desired item was not located (see table 8).

These users continued to use the card catalog: (1) For retrospective material, particularly older subjects, as in the case of the patron who was searching for historical source material on the Federal Housing Authority. (2) If too many similar titles came up online. (3) For cross-checking for items not found in the online catalog.

These findings are supported by figures from the previously mentioned OSU Poll 


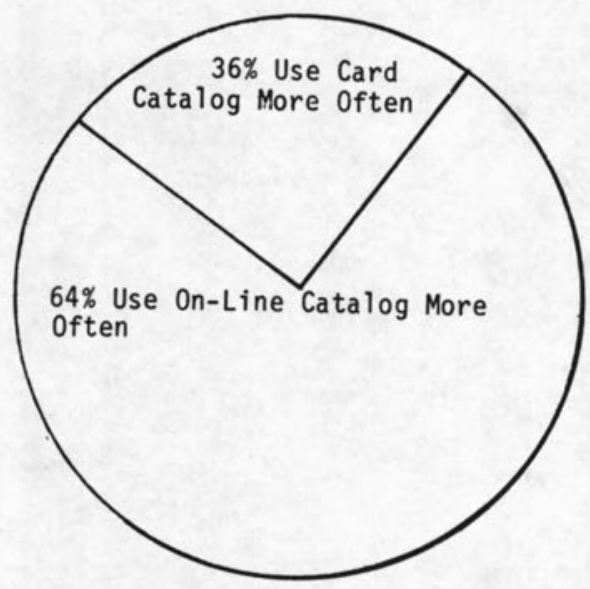

Fig. 5

Main Library Actual Searches Study Preferential Use Pattern of all Patrons Who Have Tried Online Catalog

showing that 73 percent of those who had used any catalog in the past quarter had used both online and card catalogs. ${ }^{10}$

The cross-checking behavior of online users must be examined more closely to determine if the behavior is adaptive or if it is a security mechanism taken because of a lack of confidence in using the online catalog. In table 9,87 percent of those using the online less than a year still cross-checked in the card catalog. While the intention to cross-check is reduced as the user becomes more familiar with the online catalog, 50 percent of those who have used the online catalog more than a year still cross-check.

Are these cross-checks necessary, or are they redundant and a waste of time? Results showed that 67 percent of these searches that were unsuccessful in the online catalog were successful in the card catalog. Thirty-three percent were still unsuccessful. (Of those searches that were unsuccessful the second

\section{TABLE 8}

Main Library Actual Searches Study

"If You Don't Find What You ARE SEARCHING For, Will You Use the Online Catalog?"

\begin{tabular}{lcc}
\hline & $\begin{array}{c}\text { Yes } \\
(\%)\end{array}$ & $\begin{array}{c}\text { No } \\
(\%)\end{array}$ \\
\hline $\begin{array}{l}\text { Never used online } \\
\text { Knows how to use online, } \\
\text { but went to card catalog first }\end{array}$ & 44 & 56 \\
\hline
\end{tabular}

time, two-thirds were unsuccessful the second time due to the item not being in the collection, and one-third due to user error in the card catalog.) With a 67 percent success rate, cross-checking behavior may be adaptive.

Regarding content, the online catalog contains many single items from certain microform series for which no records exist in the card catalog. The card catalog contains analytics not entered in the online catalog and making a cross-check would be adaptive on this basis. With this sample, cross-checking was not justified on the grounds of differing database content. Of those who came to the card catalog after failure in the online cata$\log$, no items in patrons' actual searches were present in only one catalog. Seventy-six percent of items had records in both catalogs and the other 24 percent did not have records in either catalog.

Results, shown in table 10, indicated that the reason patrons failed in the online and came to the card catalog were: (1) Need for points of access and full records for retrospective materials (75 percent); (2) Too many matches on titles and corporate authors (17

\section{TABLE 9}

Main Library Actual Searches Study

Percent of Online Users Who Intend to Cross-Check in Card Catalog If Desired ItEM Not Found

\begin{tabular}{lcc}
\hline \hline & $\begin{array}{c}\text { Yes } \\
(\%)\end{array}$ & $\begin{array}{c}\text { No } \\
(\%)\end{array}$ \\
\hline Used online more than a year & 50 & 50 \\
Used online less than a year & 87 & 13 \\
\hline
\end{tabular}

\section{TABLE 10}

Main Library Actual Searches Study Reasons for Failure in the Online Catalog (Patrons Who Came to the Card Catalog AFTER FAILING IN THE ONLINE)

\begin{tabular}{lcrr}
\hline & Number & Percent & $(\%)$ \\
\hline $\begin{array}{l}\text { Too many matches } \\
\text { Title }\end{array}$ & 2 & 17 & 17 \\
$\begin{array}{l}\text { Corporate Author } \\
\begin{array}{l}\text { Joint Author } \\
\text { (before 1977) }\end{array}\end{array}$ & 1 & 8 & \\
$\begin{array}{l}\text { Subjects (before 1977) } \\
\text { Wanted full biblio- }\end{array}$ & 6 & $50\}$ & \\
$\quad \begin{array}{l}\text { graphical record } \\
\quad \text { before 1977) }\end{array}$ & 2 & 17 ) & \\
$\begin{array}{l}\text { Patron error } \\
\quad \text { Totals }\end{array}$ & 1 & 8 & 8 \\
Undetermined & 12 & 100 & \\
\hline & 2 & & \\
\hline
\end{tabular}


percent); (3) Patron error in online catalog (8 percent).

This indicates that those who have never used the online catalog and those who know how to use it but do not cross-check may not be able to gain access to the microform series and other collections that are added to the online catalog but not added to the card cata$\log$.

\section{Patrons Who Have Never Tried the ONLine Catalog}

Considering those who have never become acquainted with the online catalog, we see that the library's publicity efforts have been relatively successful and that more than half of all users at the card catalog have tried the online catalog (figure 3). This is evidence of the strong effort the library has made to reach all potential users.

Table 11 shows the attitudes of those who have never tried the online catalog. Table 12 shows how these attitudes were related to class and sex factors.

Results of the Department Libraries Experimental Study indicate that the online catalog and the card catalog are mutually reinforcing systems. Continued use of the card catalog did not interfere with online catalog success and may even have slightly enhanced success. In fact, "heavy" users of the card catalog did slightly better overall than did nonusers of the card catalog (see table 13). This can also be seen in figure 6 , which shows success of online users in the card catalog in three different lengths of experience with the online catalog. Here again, card catalog success is not affected by a long period of predominantly online use.

\section{SUMMARY AND CONCLUSIONS}

The great majority of patrons found at the online catalog expressed a preference for it over the card catalog. These findings on preference are supported by actual use patterns. More than half of those who had actually tried the online catalog "switched over" to use it more often than the card catalog.

This discrepancy between preference and use may be due to the fact that, in most preference studies, only online users have been surveyed. In the authors' Actual Searches Study, users at the card catalog were also surveyed and a group of "drop-out" users was
TABLE 11

Main Libraty Actual Searches Study Attitudes of Those Who Have Never Used the Online Catalog

\begin{tabular}{lcc}
\hline & Number & Percent \\
\hline $\begin{array}{l}\text { Willingness to try } \\
\text { Prefer card catalog, } \\
\text { faster, easier }\end{array}$ & 8 & 42 \\
$\begin{array}{c}\text { Dislike computers; } \\
\text { prefer card catalog, } \\
\text { don't want to learn }\end{array}$ & 8 & 42 \\
\hline
\end{tabular}

TABLE 12

Main Libraky Actual Searches Study AtTtTudes of Users Who Have Never Tried the Online Catalog

Class and Sex

\begin{tabular}{lccc}
\hline & $\begin{array}{c}\text { Willing } \\
\text { To Learn } \\
(\%)\end{array}$ & $\begin{array}{c}\text { Prefer Card } \\
\text { Catalog; Avoid } \\
\text { Online } \\
(\%)\end{array}$ & $\begin{array}{c}\text { Dislike } \\
\text { Computers, } \\
\text { Don't Want } \\
\text { To Learn } \\
(\%)\end{array}$ \\
\hline Male & 75 & 45 & 45 \\
Female & 25 & 55 & 55 \\
Underclass & 14 & 22 & - \\
Upperclass & 57 & 56 & 50 \\
Grads & 29 & 22 & 50 \\
\hline
\end{tabular}

TABLE 13

Department Libraries Experimental Study Success in the Online Catalog Related to Card Catalog Use

\begin{tabular}{llc}
\hline \hline & \multicolumn{1}{c}{ Use of Card Catalog } & $\begin{array}{c}\text { Online Success } \\
(\%)\end{array}$ \\
\hline (nonuse) & 0 use per month & 64 \\
("heavy" use) & 5 + uses per month & 69 \\
\hline
\end{tabular}

found who had returned to predominantly card catalog use. This indicates that future studies of user behavior in regard to online catalogs should survey all online users including those found at card catalogs - if useful conclusions are to be drawn.

Patrons' use of the online catalog may be based more on their level of success in locating what they needed, rather than on personal preference. In this study, many of those who reported they were not successful with the online catalog tended to drop out and return to predominantly card catalog use, in which they were more successful.

The online catalog did not serve as a complete replacement for the card catalog for most users. The great majority of those who had tried the online catalog continued to 


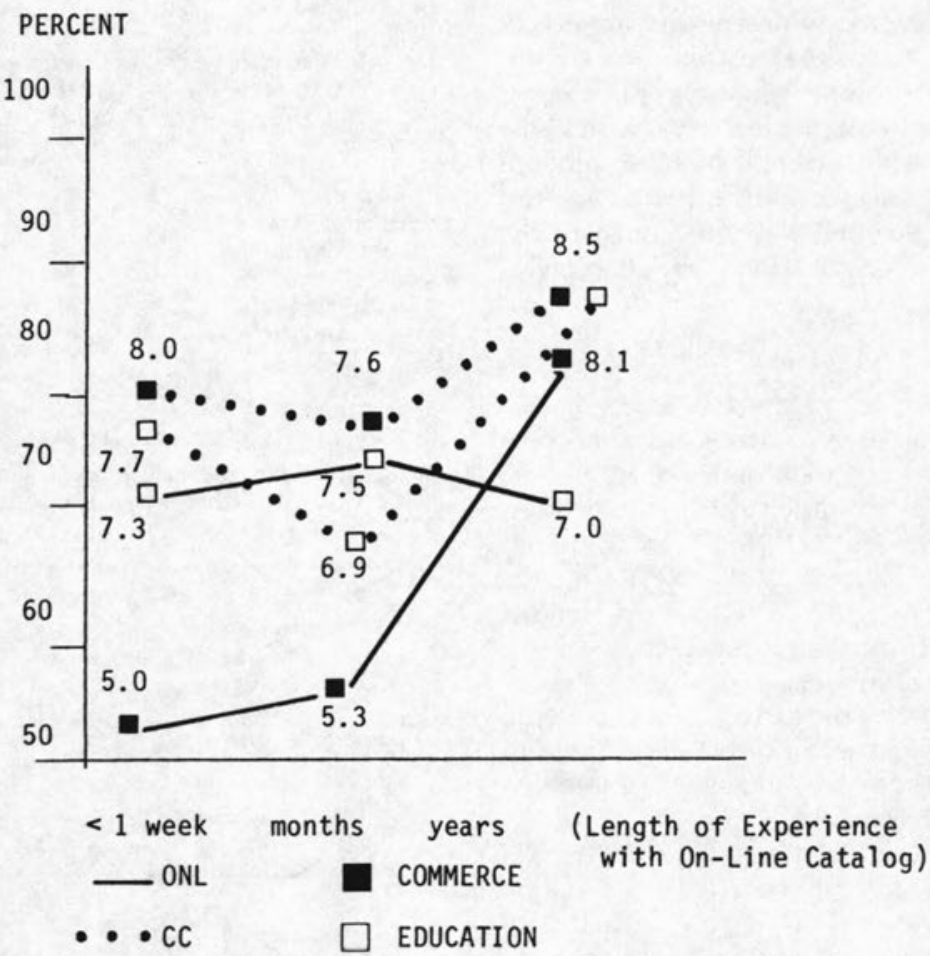

Fig. 6

Success in Each Library in the Online and Card Catalog: Education and Commerce Libraries

make some use of the card catalog.

A large number of those who had switched over to the online catalog - and developed skill - still cross-checked in the card catalog all items they did not find in the online cata$\log$, due to the lack of approaches for retrospective materials, particularly older subjects, in the online catalog. This indicates that planners of online catalogs need to provide approaches and records equal to the card catalog for all retrospective, as well as current, materials.

Another reason for continued card catalog use by online users was the use of certain algorithms producing too many matches. This problem may be solved in the future by use of several different algorithms.

The patron who fails to reach the same level of success with the online system as in the card catalog is a major concern. The library's educational programs, instructional sessions, and other efforts over the years to acquaint users with the online catalog and encourage its use have been successful, considering the large university enrollment and the constantly changing nature of the university population. However, even with the most strenuous educational efforts, some library users will not be reached and will never attain a sufficient level of skill with the online system to take full advantage of its use.

A revealing fact emerged from the OSU Poll supporting this conclusion, in that 33 percent of online users surveyed had been reached by formal workshops, 22 percent by individual instruction from library staff, and 11 percent by friends and "other methods." However, 34 percent learned from printed instructional material at the terminals. ${ }^{11}$

For this reason it is important, in addition to offering formal and informal instruction, to concentrate efforts on providing simpler terminals and instruction sheets both of 
which are designed to prevent patron errors at the point of use. Perhaps the first step in raising patron success levels on online catalogs should be to cast aside the comforting assumption that patrons will be more successful with the online catalog than the card catalog. Once we have faced this fundamental problem, the task of studying patron errors and designing improved systems and point-of-use instructions can begin in earnest.

\section{REFERENCES}

1. John Aubrey, "A Timing Study of the Manual Searching of Catalogs," Library Quarterly 42:399-415 (Oct. 1972); Robert Blackburn, "Two Years With a Closed Catalog," Journal of Academic Librarianship 4:424-29 (Jan. 1979); Mary Kay Daniels Ganning, "The Catalog; Its Nature and Prospects," Journal of Library Automation 9:48-66 (March 1976); Ruth Hafter, "The Performance of the Card Catalog; A Review of Research," Library Research 1:199-222 (Fall 1979); Ben-Ami Lipitz, "Catalog Use in a Large Research Library," Library Quarterly 42:129-39 (Oct. 1972); Carl McAllister and John M. Bell, "Human Factors in Design of an Interactive Library System," Journal of the American Society for Information Science 22:96-104 (March-April 1971); Don R. Swanson, "Requirements Study for Future Catalogs," Library Quarterly 42:302-15 (July 1972); Renata Tagliacozzo, Lawrence Rosenberg, and Manfred Kochan, "Access and Recognition: From Users' Data to Catalogue Entries," Journal of Documentation 26:230-49 (Sept. 1970).

2. Renata Tagliacozzo and Manfred Kochan, "Information Seeking Behavior of Catalog Users," Information Storage and Retrieval 6:363 (1970).

3. Jerry Specht, "Patron Use of an On-Line Cir-

\section{2}

culation System in Known-Item Searching," Journal of the American Society for Information Science 31:335-46 (Sept. 1980).

4. Kenneth Dowlin, "Users Prefer Online," Library Journal 105:1595 (Aug. 1980); Mary N. Gouke and Sue Pease, "Title Searches in an On-Line Catalog and a Card Catalog: A Comparative Study of Patron Success in Two Libraries," Journal of Academic Librarianship (in press); Carol Weiss Moore, “Users Reactions to On-Line Catalogues: An Exploratory Study" (Prepared under a grant from the Social Sciences and Humanities Research Council, Toronto, Canada); Specht, "Patron Use of an On-Line Circulation System," p.335-46.

5. Moore, "Users Reactions to On-Line Catalogues."

6. Ohio State University, Behavioral Science Laboratory, "OSU Student Poll, Library Section, Winter 1981."

7. Specht, "Patron Use of an On-Line Circulation System," p.336.

8. Moore, "Users Reactions to On-Line Catalogues."

9. Dowlin, "Users Prefer Online," p.1595.

10. Ohio State University, "OSU Student Poll, Library Section, Autumn 1980."

11. Ibid. 